\title{
Agroecosystems and Food Security Vulnerability to the Current Climate Change in South-Kivu (Democratic Republic of Congo)
}

\author{
BYENDA Mutuga Bienfait ${ }^{1}$, BABOYLonganza Louis ${ }^{2}$, BALUKU Bajope Jean Pierre ${ }^{3}$, \\ KANYENGA Lubobo Antoine ${ }^{4}$, MUNYULI Mushambanyi Theodore ${ }^{5}$ \\ ${ }^{1}$ BukavuCentral University (UBC), College of Agronomic and Veterinary Studies (ISEAV-Mushweshwe), Unit of Research and Teaching \\ in Agrosciences and Environnemnt (UREA) \\ ${ }^{2,4}$ Faculty of Agronomy, University of Lubumbashi (UNILU) \\ ${ }^{3}$ BukavuCentral University (UBC) and the Research Center in Natural Sciences (CRSN-Lwiro) \\ ${ }^{5}$ Bukavu Medical Techniques College (ISTM) and Research Center in Natural Sciences (CRSN-Lwiro)
}

\begin{abstract}
The research on the vulnerability of agroecosystems and food security to the current climate change in South-Kivu has been carried out through a questionnaire survey conducted among households exploiting agroecosystems with the overall objective of contributing to the sustainable management of agroecosystems and the understanding of the dynamics of the operation of natural resource holdings by establishing a state of the vulnerability of agroecosystems and food security as well as characterizing them. The result has showed that the food production sector in South-Kivu is highly vulnerable to climate vagaries and no system is established to strengthen endogenous capacities. Early warning systems and assurance of agricultural activities against the adverse effects of climatic variability are urgent in the region.
\end{abstract}

Keywords: Climate change, vulnerability, agroecosystems, endogenous capacities, conservation agriculture, agricultural insurance

\section{Introduction}

Africa has often been identified as one of the most vulnerable regions to climate variability and change due to multiple disruptions and low resilience resulting from endemic poverty, weak institutions and recurrent droughts, emergencies and complex conflicts associated with it [1]. The global context in Africa, and particularly sub-Saharan Africa, is very worrying because it is the most exposed region in the world. This vulnerability of sub-Saharan Africa to climate change is due to its high dependence on agriculture and its limited adaptability due to lack of resources and technologies [2] The Panel of Experts on Climate Change projections show that on the African continent current and future trends suggest that large areas, such as the Sahel, the Horn of Africa, parts of Central and Southern Africa, could be warming by 3 to $6{ }^{\circ} \mathrm{C}$ by 2100 [3]. And according to the Organization for Economic Cooperation and Development, climate is presented as an integrated factor in all African agricultural production[4], it can pass on its local variations, which change gradually to become profound and reach a stage of irreversibility.

Since crop production systems are predominantly rainfed in the South-Kivu province, variability of temperature and rainfall is an important risk factor because it can completely disrupt the nutritional capacity of the most food-insecure layers. Thus, in the peasant environment of South-Kivu, it has recently been stressed that the overexploitation of agroecosystems and the use of inappropriate agricultural practices coupled with climate variability and change have negative effects on the quality of agricultural soils which become less fertile and more vulnerable[5]. This affects the quality and quantity of agricultural production with its adverse consequences on the diet of the populations. This situation cannot lead to sustainable agriculture, the basic principle of which is to be economically sustainable, ecologically sound and socially equitable [6]

In South-Kivu province, despite the existence of agroecological zones that are very favorable to agriculture [7],[8]), food insecurity is marked by a high rate of severe acute malnutrition [8], [9]. It is known that food security exists when high quality food is available and accessible by all in a stable and permanent way [10], [11]. This food is generallyof agricultural origin and the bases of its production are agroecosystems. This requires that all factors that affect the quality and quantity of food products or that affect their stability and accessibility are taken into account in order to determine the nutritional vulnerability status of the peasant population.

Since adaptive capacities are deployed within the limits determined by a society's vulnerability [12], and vulnerability itself is a function of the character, rate and magnitude of climatic variation a system is exposed, as well as its sensitivity and adaptability [13], but it is also an expression of the level at which a natural or human system can be affected and then degraded or damaged by the impacts of climate change, including extreme events [14].it is more than a necessity to understand the vulnerability of the food production sector at the local level in order to propose solutions that meet the local sphere. This requires answering the following key question: What are the characteristics of agroecosystems and food security in relationship with climate change in the peasant communities of South-Kivu?

\section{Volume 6 Issue 12, December 2017}




\section{International Journal of Science and Research (IJSR) \\ ISSN (Online): 2319-7064}

Index Copernicus Value (2016): 79.57 | Impact Factor (2015): 6.391

In the scientific literature, studies on the vulnerability of agroecosystems, agricultural production and food security in the face of climate constraints are very rare in the region, yet they are of major benefit to scientists, decision-makers and farmers in all sustainable development programs in SouthKivu. Therefore, a reseachon the vulnerability of agroecosystems and food security to climate change in South-Kivu was considered in order to establish a state of vulnerability of agroecosystems and food security related to climate change in the region. This reseach is being carried out with a view to adapting to climate change and the sustainable management of natural resources for the promotion of food security. In this study, vulnerability refers to the characteristics of agroecosystemsand food security that determine their ability to anticipate, cope, resist and recover from the impacts of climatic hazards (temperature and rainfall), the variation of which would be natural or anthropogenic.

The hypothesis of this study states that the vulnerability of agroecosystems and food security would be characterized by the degradation of agroecosystems, lack of assurances against climate risks, land scarcity, low production and food insecurity in connection with variability of climatic factors. In order to achieve this study, a survey of 422 rural household heads in South-Kivu was organized to collect primary data. Secondary data were provided by three institutions: the National Nutrition Program, the Agricultural Inspectorate and the Meteorological Station of the Lwiro Natural Science Research Center.

\section{Methodology}

\subsection{Study Framework}

South-Kivu is a province of the DR Congo situated in the eastern part between $00^{\circ} 58^{\prime} 0^{\prime \prime}$ north latitude, $4^{\circ} 51^{\prime} 21^{\prime \prime}$ south latitude and $26^{\circ} 10^{\prime} 30^{\prime \prime}$ east longitude. The altitude varies between 700 and $3000 \mathrm{~m}$. Its surface area is 66.814 square kilometers and the population is 6.455 .592 (Statistics of the Ministry of the Interior 2015). The province of South-Kivu has a total of 8 territories including Fizi, Uvira, Kabare, Kalehe, Walungu, Shabunda, Mwenga and Idjwi. The latter is an island in Lake Kivu. The territories of Kabare, Kalehe, Idjwi, Walungu and Uvira were surveyed in this study because they are among the most vulnerable areas to the phenomenon of climate variation.

Indeed, a recent study in these five territories has shown that in South-Kivu, in the conduct of activities within agroecosystems, household heads encounter many constraints, the major ones being: disruption, unpredictability irregular rains, scarcity of arable land, poverty and loss of soil fertility, water erosion, crop diseases and pests, degeneration of seeds and less potent varieties, perception of temperatures, lack of financial resources, low production, cropping of marginal land, poor cropping techniques for soil conservation, low investment in land protection and improved productivity[5]. And in a food security analysis, Kabare, Walungu, Uvira, and Idjwi territories were classified as under-pressure and had a severe acute malnutrition rate exceeding the two per cent severity threshold [8]. That is why they were interesting in this study. Primary data were collected for two consecutive years 2015 and 2016.

\subsection{Equipment}

In carrying out this study, the questionnaire was used to collect primary data. The data used were obtained from field surveys carried out for two consecutive years (from 2015 to 2016) in order to collect the socio-economic data of the farmers, the different causes of the vulnerability, to identify the indicators of the degradation of agro-ecosystems, food insecurity and production. These data were supplemented by field observations and statistics obtained from specialized services.

\subsection{Method}

The primary data from this study, obtained through the survey questionnaire, were supplemented by secondary data, which included historical data on agricultural production, livestock production, prevalence of malnutrition, meteorological data (temperature and rain) in South-Kivu. Data on prevalence of malnutrition were obtained at PRONANUT (National Nutrition Program), historical data on precipitation and temperature in the region were collected from the archives of the Meteorological Station CRSN (Research Center in Natural Sciences of Lwiro) and the data relating to the production of food, industrial and fruit crops, livestock and fisheries were obtained from the IPAPEL (Provincial Inspectorate of Agriculture, Fisheries and Livestock).

\section{- Sample, characteristics of the subjects and criteria for inclusion in the study:}

At the study sites (Idjwi, Kabare, Kalehe, Uvira and Walungu), a peasant who was at least 30 years of fixed residence in South-Kivu, who was between 35 and 70 years, and was engaged or still engaged in agricultural activities, was eligible to participate in the investigation. The respondent had to be in a household located on the researcher's itinerary by following the orientation of the tip of a rotated pen on the ground from a point chosen as the middle of the site. Each after three households, the next one was investigated if he consents to participate in the study and if not it was the next household that became the immediate target and in each household one of the person in charge was interviewed.

The sample size for this study was 422 farm households with a population of 3132660 . It is known that the national average of persons per household in the Democratic Republic of Congo is 6.8 and that in the province of South Kivu in particular it is 7, [9]. This gives a set of 447522 households. For a mother population of more than 100,000 households and less than 500000 households if a sample is selected for $\mathrm{P}=0.5$ and a confidence level of $95 \%$ is therefore $\mathrm{t}=1.96$ of precision and a margin of error of 0.05 , the table of TAKTO (http://www.takto.qc.ca/infotakto/it0402) gives thesample size of 384 households. In order to try to bring the numbers closer together and to correct any "nonresponse" cases, in view of the very heterogeneous distribution of the population on the route and the chance that characterizes the affiliation of a household meeting the conditions of eligibility for the surveyor's route, the overall 


\section{International Journal of Science and Research (IJSR) \\ ISSN (Online): 2319-7064}

Index Copernicus Value (2016): 79.57 | Impact Factor (2015): 6.391

sample for all five territories was set at 422 agricultural households, that is, 384 households increased by $10 \%$ (38 households). Based on the total number of households in each territory, the sample was distributed as follows: 30 in Idjwi, 93 in Kabare, 80 in Kalehe, 118 in Walungu and 101 in Uvira.

\section{- Data processing and analysis:}

The raw data collected were encoded in Excel 2007. Preliminary analyzes consisted of conducting descriptive statistical analyzes by means of averaging, standard deviation, standard error of the average, coefficient of variation, maximum, minimum, mode, distribution of climatic factors, production and prevalence of malnutrition. Single and multiple regressions and logarithmic transformations of some data were used to detect linkages between climatic factors and food production or the prevalence of malnutrition, degradation of agroecosystems and correlations. The types of data distribution were verified by submitting the data to the Kolmogorow-Smirnov test. All the statistical analyzes including the generalized linear models (GLM), were thus built in the software STATA version 11 for windows 2012.

\section{Results}

\subsection{Sociodemographic and professional characteristics of the respondents in 2015-2016.}

The results of surveys conducted by heads of rural agricultural households in South-Kivu in relation to vulnerability of agroecosystems and food security were obtained by men $(52.61 \%)$ and women $(47.39 \%)$ who participated in the study. This reflects the representative character of men and women in the survey and therefore in the subsequent analysis endogenous knowledge is valid for both men and women throughout the region. In the agricultural households surveyed, $56.87 \%$ each have the population of persons generally between six and sixteen with an arithmetic average of 8 persons. This reflects the fact that families are overflowing in all the territories under study in South-Kivu, which is an indicator of a lack of family planning in rural families and therefore may be a brake on development given low income in households.

\subsection{Knowledge on agroecosystems vulnerability indicators}

In Table-1 below, which presents knowledge related to conflicts in the conduct of agricultural activities, the majority of farmers $(61.37 \%)$ acknowledge that an increase in land conflicts is a current characteristic of activities in South-Kivu agroecosystems $\left(\chi^{2}=40.90, P<0.001, \mathrm{Df}=4\right)$. According to the majority of farmers $(71.09 \%)$ these conflicts are mainly between farmers and stockbreeders $\left(\chi^{2}=57.06, P<0.001\right.$, $\mathrm{Df}=4)$ and are due to roadblocks and animal corridors, ravages and crops destruction by the beasts and often the bush fire in search of pastures. According to some peasants $(4.73 \%)$, conflicts over inheritance lands between family members during the succession $\left(\chi^{2}=18.50, P=0.001\right.$, Df $=$ 4 ) and according to others $(8.29 \%)$ it is the spoliation of the fields which causes the conflicts between the peasants in South-Kivu $\left(\chi^{2}=14.85, P=0.005 \mathrm{Df}=4\right)$. Some farmers sometimes have complex conflicts in which farmers, breeders, family members are in conflict of succession also involving spoliation $\left(\chi^{2}=21.71, P<0.001, \mathrm{Df}=4\right)$. This means that there is a high level of tension among the population in the exploitation of agroecosystems, which can undermine the proper conduct of activities.

In relation to farmers' knowledge of the availability of arable land and the occupation of land by agricultural activities, Table-2 shows that, according to $34.12 \%$ of the farmers surveyed, the land acquisition mode is generally inheritance $\left(\chi^{2}=57.31, P<0.001, \mathrm{Df}=4\right)$ by which descendants inherit the land their parents used to work from generation to generation. Given the assertions of the majority of farmers $(65.87 \%)$ that farmland by family is becoming more scarce at present, as a result of enrolment that increases considerably from father to son $\left(\chi^{2}=60.02, P<0.001\right.$, Df $\left.=4\right)$ farmers use other ways of increasing arable land including land leasing, purchase, donation and borrowing. This method of borrowing a plot of land is much less common and less practiced in South-Kivu because only $1.42 \%$ of the peasants have already experimented it to increase their spaces. However, many farmers $(56.87 \%)$ acknowledge that the scarcity of land on which to manage agroecosystems has negative repercussions on areas by reducing fallow and especially by lowering household income $\left(\chi^{2}=56.58, P<\right.$ 0.001 , Df $=4)$. In addition, agricultural mechanization is still in its infancy as currently $94.31 \%$ of the farmers included in the study are using hoes and the perception of the area planted is still shared as $47.86 \%$ of the respondents believe that the area increases while $41.94 \%$ of them state that the area is decreasing. It has been found that those who have the opportunity to lease the land of the poor are those who have claimed that the areas sown are currently increasing. The fact that the poorest person leases his land makes him even more miserable and he finally enters the landless peasant class that is gaining momentum in the heavily anthropized rural areas of South-Kivu as in Idjwi, Kabare, Kalehe and Walungu.

Table- 3 on infrastructure for adaptive capacity shows that in the peasant communities of South Kivu there are some social infrastructures in good condition, such as health centers, schools, markets, drinking water and agricultural service roads but cover only a small part of the region and reflect vulnerability to climate change. According to the knowledge of rural peasants $(61.84 \%)$, out-of-school youth are less interested in agriculture and prefer rural exodus $\left(\chi^{2}=61.84\right.$, $P<0.001$, Df $=4)$, since there is no formal regulation of the selling price of agricultural products in South Kivu according to $91.94 \%$ of the peasants surveyed. In this case farmers recognize that the price of agricultural products is less interesting and it discourages them very significantly $\left(\chi^{2}=\right.$ 57.74, $P<0.001$, Df = 4)

Table-4 shows that agricultural farmers $(77.25 \%$ of respondents) recognize that their crops are increasingly being attacked by pests in all the territories of South-Kivu $\left(\chi^{2}=\right.$ $56.14, P<0.001$, Df $=4)$, the main pests are caterpillars, mealybugs, mites, aphids, weevils, rats, moles and birds, and the main diseases are mosaic, banana wilt, brown cassava, bacterial wilt, moles, acariosis, and anthracnose. Many of the peasants $(61.37 \%)$ have no possibility of combating pests $\left(\chi^{2}\right.$ $=40.90, P<0.001 \mathrm{Df}=4)$ and this, according to the

\section{Volume 6 Issue 12, December 2017}




\section{International Journal of Science and Research (IJSR) ISSN (Online): 2319-7064 \\ Index Copernicus Value (2016): 79.57 | Impact Factor (2015): 6.391}

knowledge of the majority of farmers $(80.09 \%)$, leads to decreased crops $\left(\chi^{2}=56.05 P<0.001\right.$, Df $\left.=4\right)$.

Table 1: Knowledge about the types of conflicts in the conduct of activities within agroecosystems

\begin{tabular}{|c|c|c|c|}
\hline Variables & $\begin{array}{l}\text { Frequency: } \\
\mathrm{N}=422(\%)\end{array}$ & $\chi^{2}$ & $\mathrm{P}$-Value \\
\hline \multicolumn{4}{|c|}{ Land conflicts between the different layers } \\
\hline Increase & $259(61.37)$ & 40.90 & $<0.001$ \\
\hline Stable & $48(11.37)$ & 31.37 & $<0.001$ \\
\hline Decrease & $84(19.90)$ & 63.26 & $<0.001$ \\
\hline Do not know & $31(7.34)$ & 27.54 & $<0.001$ \\
\hline \multicolumn{4}{|c|}{ Conflict types } \\
\hline Farmers - Breeders & $300(71.09)$ & 57.06 & $<0.001$ \\
\hline Spoliation of agro-ecosystems & $35(8.29)$ & 14.85 & 0.005 \\
\hline Succession & $20(4.73)$ & 18.5 & 0.001 \\
\hline Breeders - Breeders & $4(0.94)$ & 16 & 0.003 \\
\hline All of the above & $14(3.31)$ & 21.71 & $<0.001$ \\
\hline Farmer Breeder and spoliation & $29(6.87)$ & 23.24 & $<0.001$ \\
\hline Farmer Breeder and succession & $20(4.73)$ & 14.5 & 0.006 \\
\hline Spoliation and succession & $0(0.00)$ & & NST \\
\hline
\end{tabular}

Table 2: Perception of current availability and occupation of arable land in agroecosystems and their impacts on agricultural activities in South-Kivu

\begin{tabular}{|c|c|c|c|}
\hline Variables & $\begin{array}{l}\text { Frequency: } \\
\mathrm{N}=422(\%)\end{array}$ & $\chi^{2}$ & P-Value \\
\hline \multicolumn{4}{|c|}{ Modes of land acquisition } \\
\hline Inheritance & $144(34.12)$ & 57.31 & $<0.001$ \\
\hline Donation & $25(5.92)$ & 16 & 0.003 \\
\hline Purchase & $67(15.87)$ & 33.97 & $<0.001$ \\
\hline Rental & $78(18.48)$ & 80.07 & $<0.001$ \\
\hline Loan & $6(1.42)$ & 10.66 & 0.031 \\
\hline All the above & $19(4.50)$ & 10.21 & 0.037 \\
\hline Inheritance and donation & $12(2.84)$ & 23.83 & $<0.001$ \\
\hline $\begin{array}{l}\text { Inheritance, purchase and } \\
\text { rental }\end{array}$ & $53(12.55)$ & 42.75 & $<0.001$ \\
\hline Purchase and loan & $4(0.94)$ & 8.5 & 0.075 \\
\hline Inheritance and loan & $11(2.60)$ & 6.72 & 0.151 \\
\hline Rental and loan & $3(0.71)$ & 35.07 & $<0.001$ \\
\hline Donation and loan & $0(0.00)$ & & PST \\
\hline \multicolumn{4}{|c|}{ Availability of land for agriculture } \\
\hline Lots of land & $144(34.12)$ & 46.90 & $<0.001$ \\
\hline Scarcity of land & $278(65.87)$ & 60.02 & $<0.001$ \\
\hline Reduction of fallows & $94(22.27)$ & 25.68 & $<0.001$ \\
\hline Decrease in income & $240(56.87)$ & 56.58 & $<0.001$ \\
\hline Others & $37(8.76)$ & 45.29 & $<0.001$ \\
\hline $\begin{array}{l}\text { Reduction of fallow and } \\
\text { income }\end{array}$ & $51(12.08)$ & 111.05 & $<0.001$ \\
\hline Hoes & $398(94.31)$ & 48.71 & $<0.001$ \\
\hline Tractor & $24(5.68)$ & 11.41 & 0.022 \\
\hline \multicolumn{4}{|c|}{ Estimation of currently sown areas compared to the past } \\
\hline Increase & $202(47.86)$ & 91.81 & $<0.001$ \\
\hline Decrease & $177(41.94)$ & 23.70 & $<0.001$ \\
\hline No change & $43(10.18)$ & 16.65 & 0.002 \\
\hline \multicolumn{4}{|c|}{$\begin{array}{l}\text { Legend: The different levels of the test meaning are indicated } \\
\text { by the values of P; Ns = test not significant }\end{array}$} \\
\hline
\end{tabular}

Table 3: Knowledge of social infrastructure for adaptation to climate change

\begin{tabular}{|c|c|c|c|}
\hline Variables & $\begin{array}{l}\text { Frequency: } \\
\mathrm{N}=422(\%)\end{array}$ & $\chi^{2}$ & P-Value \\
\hline \multicolumn{4}{|c|}{ Social infrastructures in the community } \\
\hline Health center & $31(7.34)$ & 14.32 & 0.006 \\
\hline School & $138(32.70)$ & 53.37 & $<0.001$ \\
\hline Market & $26(6.16)$ & 55.92 & $<0.001$ \\
\hline Electricity & $0(0.00)$ & & \\
\hline Drinking $\mathrm{w}$ & $28(6$. & 13.42 & 0.009 \\
\hline Road & $17(4$. & 14.62 & 0.006 \\
\hline Bank & $5(1.1$ & 8 & 0.092 \\
\hline Cereal bank & & & \\
\hline $\begin{array}{c}\text { Health center, School and } \\
\text { Potable water } \\
\end{array}$ & $138(32.70)$ & 25.98 & $<0.001$ \\
\hline School, market and potable water & $39(9.24)$ & 42.92 & $<0.001$ \\
\hline \multicolumn{4}{|c|}{ Out of school youth and agriculture } \\
\hline They are very interested & $161(38.15)$ & 52.07 & $<0.001$ \\
\hline They are less interested & $\begin{array}{r}261 \\
(61.84)\end{array}$ & 61.62 & $<0.001$ \\
\hline \multicolumn{4}{|c|}{ Selling price of agricultural products } \\
\hline Very interesting & $34(8.05)$ & 44.23 & $<0.001$ \\
\hline Less interesting & $388(91.94)$ & 57.74 & $<0.001$ \\
\hline \multicolumn{4}{|c|}{$\begin{array}{c}\text { Legend: The different levels of the test meaning are indicated by } \\
\text { the values of P; Ns = non-significant test, PNT = not applied } \\
\text { statistical tests }\end{array}$} \\
\hline
\end{tabular}

Table 4: Peasant knowledge on crop attack by pests in agroecosystems under climate disturbance conditions in SouthKivu

\begin{tabular}{|c|c|c|c|}
\hline Variables & $\begin{array}{l}\text { Frequency: } \\
\mathrm{N}=422(\%)\end{array}$ & $\chi^{2}$ & P-Value \\
\hline \multicolumn{4}{|c|}{ Attack of crops by predators and diseases } \\
\hline More attacked & $326(77.25)$ & 56.14 & $<0.001$ \\
\hline Less attacked & $73(17.29)$ & 50.49 & $<0.001$ \\
\hline No change & $23(5.45)$ & 24.17 & $<0.001$ \\
\hline \multicolumn{4}{|c|}{ Major plant pests currently registered } \\
\hline Caterpillars and mealybugs & $116(27.48)$ & 21.24 & $<0.001$ \\
\hline Mites & $44(10.42)$ & 19.40 & 0.001 \\
\hline Aphid & $33(7.81)$ & 2.60 & 0.62 \\
\hline Weevils & $72(17.06)$ & 31.33 & $<0.001$ \\
\hline Rats and moles & $81(19.19)$ & 12.76 & 0.012 \\
\hline Birds & $76(18.01)$ & 19.13 & 0.001 \\
\hline \multicolumn{4}{|c|}{ Major plant diseases } \\
\hline Mosaic & $92(21.8)$ & 27.89 & $<0.001$ \\
\hline Banana bacterial wilt & $104(24.64)$ & 34.36 & $<0.001$ \\
\hline Brown brunette & $39(9.24)$ & 6 & 0.199 \\
\hline Bacterial wilt & $97(22.98)$ & 43.77 & $<0.001$ \\
\hline Soft rot & $28(6.63)$ & 0.92 & 0.920 \\
\hline Acariosis & $21(4.97)$ & 3.52 & 0.474 \\
\hline Rosette & $15(3.55)$ & 6.66 & 0.155 \\
\hline Anthracnose & $26(6.16)$ & 25.15 & $<0.001$ \\
\hline \multicolumn{4}{|c|}{ Means of combating pests } \\
\hline No means & $259(61.37)$ & 40.90 & $<0.001$ \\
\hline $\begin{array}{c}\text { Chemical control by } \\
\text { insecticide }\end{array}$ & $48(11.37)$ & 31.37 & $<0.001$ \\
\hline $\begin{array}{c}\text { Mechanical control by tearing } \\
\text { of diseased plants }\end{array}$ & $84(19.90)$ & 63.26 & $<0.001$ \\
\hline \begin{tabular}{|l|} 
Biological control \\
\end{tabular} & $31(7.34)$ & 27.54 & $<0.001$ \\
\hline $\begin{array}{r}\text { Legend: The different leve } \\
\text { indicated by } \mathrm{t}\end{array}$ & $\begin{array}{l}\text { ls of meaning } \\
\text { he values of }\end{array}$ & of the te & st are \\
\hline
\end{tabular}




\section{International Journal of Science and Research (IJSR) ISSN (Online): 2319-7064}

Index Copernicus Value (2016): 79.57 | Impact Factor (2015): 6.391

\subsection{Determinants of knowledge on indicators of} vulnerability of agroecosystems to climate change

As for the consistency in farmers' responses to agroecosystem vulnerability characteristics and connections with climatic variability, the generalized linear model (GLM) testing the influences of dependent factors on independent factors reported that two factors, including knowledge of the agricultural calendar and its current disturbances(GLM: Z = 2.72 and $P=0.0017)$ and the existence of several land conflicts between farmers and herders (GLM: $\mathrm{Z}=3.38, P=$ 0.001 ) had a positive influence on the level of knowledge of the impacts of climate change on the occupation of space by agroecosystems (Table-5), while factors that had a positive influence on knowledge of the labor force were the evolution of the sown area (GLM: $\mathrm{Z}=2.55 \quad P=0.011$ ), the highly accentuated exploitation of marginal land (GLM: $Z=4.68$, $P=0.001)$, and the existence of many land conflicts between farmers (GLM: $\mathrm{Z}=2.26, P=0.024$ ) and the factor that had a negative influence was knowledge of the surveyed agricultural calendar (GLM: $\mathrm{Z}=-5.27, \quad P<0.001)$.Table-6. The level of knowledge of the existence of land conflicts in agricultural activities was associated with the workforce in agroecosystems (GLM: $\mathrm{Z}=2.26, P=0.024$ ) and knowledge of the impacts on land occupation (GLM: $\mathrm{Z}=3.38, P=$ $0.001)$ and the availability of arable land (GLM: $Z=-4.45$, $P<0.001)$ and the evolution of the area sown (GLM: $\mathrm{Z}=-$ $4.25, P<0.001$ ) had a negative influence (Table-7). In relation to knowledge on the intensity of extreme climatic events, the factor that had a positive influence was the area or study site (GLM: $\mathrm{Z}=2.65, P=0.008$ ) and those with a negative influence were the current existence of good season indicators (GLM: $\mathrm{Z}=-4.75, P<0.001$ ) and the types of indicators for good seasons (GLM: $\mathrm{Z}=-5.44, P<0.001$ ) (Table-8).

Table 5: Generalized Linear Models (GLM) testing the influences of independent factors (socio-demographic data,

knowledge on the occupation of space) on knowledge of climatic disturbances and their impacts on the occupation of agroecosystems in South-Kivu, DR Congo

\begin{tabular}{|c|c|c|c|c|}
\hline $\begin{array}{c}\text { GLM: Gaussian identity } \\
\text { model Dependent variable: } \\
\text { Knowledge about the } \\
\text { impact of climate change } \\
\text { on the occupation of } \\
\text { agroécosystèmes }\end{array}$ & Coef. & $\begin{array}{c}\text { OIM } \\
\text { Std. Err. }\end{array}$ & $\mathrm{Z}$ & $\mathrm{P}>|\mathrm{z}|$ \\
\hline Independent variables & & & & \\
\hline Territory or study site & .0201703 & .0239058 & 0.84 & 0.399 \\
\hline Sex of the respondent & -.053167 & .0531755 & -1.00 & -1.00 \\
\hline Age of the respondent & -.007034 & .006255 & -1.12 & 0.261 \\
\hline Main activity & .0397188 & .0568451 & 0.70 & 0.485 \\
\hline $\begin{array}{c}\text { Number of children per } \\
\text { household }\end{array}$ & .0086964 & .0125087 & 0.70 & 0.487 \\
\hline Evolution of the area sown & .0667352 & .0537882 & 1.24 & 0.215 \\
\hline Who work on the fields & .0539875 & .0524395 & 1.03 & 0.303 \\
\hline Natural fallow period & .0682103 & .0385656 & 1.77 & 0.077 \\
\hline $\begin{array}{c}\text { Knowledge of the } \\
\text { agricultural calendar }\end{array}$ & .139664 & .0514415 & 2.72 & $\mathbf{0 . 0 0 7}$ \\
\hline Method of land acquisition & .0137298 & .0183317 & 0.75 & 0.454 \\
\hline Availability of arable lands & .0241173 & .0510964 & 0.47 & 0.637 \\
\hline $\begin{array}{c}\text { Consequences of non- } \\
\text { availability of land }\end{array}$ & -.015445 & .0595481 & -0.26 & 0.795 \\
\hline Evolution of the fallow area & -.041815 & .0535141 & -0.78 & 0.435 \\
\hline Evolution the areas with & -.013544 & .0561097 & -0.24 & 0.809 \\
\hline
\end{tabular}

\begin{tabular}{|c|l|l|l|l|}
\hline vegetation & & & & \\
\hline Use of marginal lands & -.014830 & .0510704 & -0.29 & 0.772 \\
\hline Existence of land disputes & .1733205 & .0512244 & 3.38 & $\mathbf{0 . 0 0 1}$ \\
\hline Type of conflicts & -.021261 & .0284028 & -0.75 & 0.454 \\
\hline Constant & .9782993 & .3027539 & 3.23 & $\mathbf{0 . 0 0 1}$ \\
\hline Other statistics : Number of observations $=422 ;$ Log likelihood \\
$=-289.9464011 ;$ AIC (Akaike's Information Criterion) $=$ \\
1.459462; BIC (Schwarz's Bayesian Criterion) = -2344.543 \\
\hline
\end{tabular}

Table 6: Generalized Linear Model (GLM) testing the influences of independent factors (knowledge about the occupation of space) on the workforce working in agroecosystems in South-Kivu, DR Congo.

\begin{tabular}{|c|c|c|c|c|}
\hline $\begin{array}{l}\text { GLM: Gaussian identity } \\
\text { model } \\
\text { Dependent variable: Who } \\
\text { work in the fields }\end{array}$ & Coef. & \begin{tabular}{|c} 
OIM \\
Std. Err.
\end{tabular} & $\mathrm{Z}$ & $\mathrm{P}>|\mathrm{z}|$ \\
\hline Independent Variables & & & & \\
\hline $\begin{array}{l}\text { Knowledge on the impact of } \\
\text { climate change on the } \\
\text { occupation of } \\
\text { agroécosystèmes }\end{array}$ & .0484681 & .0470784 & 1.03 & 0.303 \\
\hline Territory or study site & -.003701 & .0226701 & -0.16 & 0.870 \\
\hline Sex o & .0538 & .0503752 & 1.07 & 0.285 \\
\hline Age of & .0005193 & .0059359 & 0.09 & 0.930 \\
\hline & -.015092 & .0538883 & -0.28 & 0.779 \\
\hline $\begin{array}{r}\begin{array}{r}\text { Number o } \\
\text { hou }\end{array} \\
\end{array}$ & -.005522 & .0118559 & -0.47 & 0.641 \\
\hline Evolution o & .1290468 & .0506564 & 2.55 & 0.011 \\
\hline Natur & .0028767 & .036682 & 0.08 & 0.937 \\
\hline $\begin{array}{r}\text { Knowledge o } \\
\text { caler }\end{array}$ & -.25073 & .0475754 & -5.27 & 0.000 \\
\hline Method of & 0010 & .0173813 & 0.06 & 0.952 \\
\hline Availabi & -.00803 & .0484257 & -0.17 & 0.868 \\
\hline $\begin{array}{r}\text { Conse } \\
\text { avail } \\
\end{array}$ & .004941 & .0564262 & 0.09 & 0.930 \\
\hline Evolution of the fallow area & -.027255 & .050725 & -0.54 & 0.591 \\
\hline $\begin{array}{r}\text { Evolution the are } \\
\text { vegetation }\end{array}$ & .0183701 & .0531602 & 0.35 & 0.730 \\
\hline Use of 1 & .2204225 & .0471356 & 4.68 & 0.000 \\
\hline Existence & .1102976 & .0489114 & 2.26 & $\mathbf{0 . 0 2 4}$ \\
\hline & .0044425 & .0269295 & 0.16 & 0.869 \\
\hline Constance & 1.099864 & .2853447 & 3.85 & 0.000 \\
\hline \multicolumn{5}{|c|}{$\begin{array}{l}\text { Other statistics: Number of observations }=422 ; \text { Log likelihood } \\
=-267.1907878 ; \text { AIC }(\text { Akaike's Information Criterion })= \\
1.351615 ; \quad \text { BIC }(\text { Schwarz's Bayesian Criterion })=-2354.525\end{array}$} \\
\hline
\end{tabular}

Table 7: Generalized Linear Model (GLM) testing the influence of independent factors (socio-demographic data, spatial occupation knowledge) on knowledge of the existence of land conflicts in the occupation of agroécosystèmes in South-Kivu, DR Congo.

\begin{tabular}{|c|c|c|c|c|}
\hline $\begin{array}{c}\text { GLM : Gaussian } \\
\text { identity model } \\
\text { Dependent variable: } \\
\text { Existence of land } \\
\text { disputes }\end{array}$ & Coef. & $\begin{array}{c}\text { OIM } \\
\text { Std. Err. }\end{array}$ & $\mathrm{Z}$ & $\mathrm{P}>|\mathrm{z}|$ \\
\hline Independent variables & & & & \\
\hline Use of bottoms & .0739601 & .0487805 & 1.52 & 0.129 \\
\hline $\begin{array}{c}\text { Availability of arable } \\
\text { land }\end{array}$ & -.212683 & .0477951 & -4.45 & $\mathbf{0 . 0 0 0}$ \\
\hline $\begin{array}{c}\text { Knowledge of the } \\
\text { agricultural calendar }\end{array}$ & -.023880 & .0497027 & -0.48 & 0.631 \\
\hline $\begin{array}{c}\text { Who work in the fields } \\
\text { (labor) }\end{array}$ & .112702 & .0499777 & 2.26 & $\mathbf{0 . 0 2 4}$ \\
\hline $\begin{array}{c}\text { Knowledge on the impact } \\
\text { of climate change on the }\end{array}$ & .158993 & .04699 & 3.38 & $\mathbf{0 . 0 0 1}$ \\
\hline
\end{tabular}

\section{Volume 6 Issue 12, December 2017}




\section{International Journal of Science and Research (IJSR) \\ ISSN (Online): 2319-7064}

Index Copernicus Value (2016): 79.57 | Impact Factor (2015): 6.391

\begin{tabular}{|c|c|c|c|c|}
\hline $\begin{array}{c}\text { occupation of } \\
\text { agroecosystems }\end{array}$ & & & & \\
\hline Territory or study site & .0094521 & .0229118 & 0.41 & 0.680 \\
\hline Sex of the respondent & -.023628 & .0509796 & -0.46 & 0.643 \\
\hline Age of the respondent & -.001803 & 0059996 & -0.30 & 0.764 \\
\hline Main activity & -.042304 & .0544371 & -0.78 & 0.437 \\
\hline $\begin{array}{l}\text { Number of children per } \\
\text { household }\end{array}$ & -.005304 & .0119848 & -0.44 & 0.658 \\
\hline Evolution the area sown & -.214526 & .0504996 & -4.25 & 0.000 \\
\hline Natural fallow period & -.015383 & .0370721 & -0.41 & 0.678 \\
\hline Land acquisition method & -.000249 & .0175698 & -0.01 & 0.989 \\
\hline $\begin{array}{l}\text { Consequence of non- } \\
\text { availability of land }\end{array}$ & -.033574 & .057014 & -0.59 & 0.556 \\
\hline Fallow area evolution & .040574 & .0512535 & 0.79 & 0.429 \\
\hline $\begin{array}{l}\text { Evolution of the areas } \\
\text { with vegetation }\end{array}$ & .0093079 & .0537425 & 0.17 & 0.862 \\
\hline Type of conflicts & .0288372 & .0271846 & 1.06 & 0.289 \\
\hline Constance & 1.801599 & .2796821 & 6.44 & 0.000 \\
\hline
\end{tabular}

conflict, $\left(\chi^{2}=66.32, P<0.001\right.$, Df $\left.=4\right)$, and many of them are unable to satisfy the needs that prove to be enormous without succeeding because the income from current activities within the agroecosystems does not even cover the primary needs $(51.42 \%)$ have no other resources $\left(\chi^{2}=56.52\right.$, $P<0.001$, Df $=4)$. Some $(34.36 \%)$ of peasant farmers engage in petty trade but the impact is not very significant $\left(\chi^{2}=9.44, P=0.05, \mathrm{Df}=4\right)$ while others rely on the diaspora and expect help from living pets elsewhere while the majority $(62.55 \%)$ have no other resources and therefore are destined to live miserably $\left(\chi^{2}=87.96, P<0.001\right.$, Df $\left.=4\right)$. According to the survey participants, many of the consequences flow from this situation, as $15.16 \%$ of the respondents say that some people prefer rural exodus $\left(\chi^{2}=\right.$ $18.03 \mathrm{P}=0.001, \mathrm{Df}=4)$ negligible $(36.01 \%)$ is in a major difficulty of enrolling their children and paying for health care $\left(\chi^{2}=57.53, P<0.001\right.$, Df $\left.=4\right)$. According to $20.85 \%$ of the respondents, the same family can be victimized and suffer many harmful consequences and lose all hope of reconstitution with a view to adaptation.

Table 8: Generalized Linear Model (GLM) testing the influences of independent factors (socio-demographic data and climatic events and their intensity) on knowledge of the intensity of extreme climate events in South Kivu, November 2015- April 2016.

\begin{tabular}{|c|c|c|c|c|}
\hline $\begin{array}{c}\text { GLM: Gaussian identity } \\
\text { model } \\
\text { Dependent Variable: } \\
\text { Intensity of Extreme } \\
\text { Climate Events in the } \\
\text { region } \\
\end{array}$ & Coef. & $\begin{array}{c}\text { OIM } \\
\text { Std. Err. }\end{array}$ & $\mathrm{Z}$ & $\mathrm{P}>|\mathrm{z}|$ \\
\hline \multicolumn{5}{|l|}{ Independent variables } \\
\hline $\begin{array}{c}\text { Existence of indicators for } \\
\text { good rainy seasons }\end{array}$ & .028457 & .0462809 & 0.61 & 0.539 \\
\hline $\begin{array}{c}\text { Current existence of } \\
\text { indicators of good rainy } \\
\text { seasons }\end{array}$ & -.226750 & .0477073 & -4.75 & 0.000 \\
\hline $\begin{array}{c}\text { Validity of these } \\
\text { indicators }\end{array}$ & .024313 & .0524742 & 0.46 & 0.643 \\
\hline $\begin{array}{l}\text { Existence of good rain } \\
\text { indicators in the past }\end{array}$ & .0655778 & .0534587 & 1.23 & 0.220 \\
\hline $\begin{array}{l}\text { Knowledge of seasonal } \\
\text { indicators (dry and rainy) }\end{array}$ & .0004663 & .0197359 & 0.02 & 0.981 \\
\hline Territory or study site & .1196022 & .045098 & 2.65 & 0.008 \\
\hline Sex of the respondent & -.003529 & .0051069 & -0.69 & 0.489 \\
\hline Age of the respondent & -.025598 & .0436409 & -0.59 & 0.557 \\
\hline Main activity & -.012013 & .0122013 & -0.98 & 0.325 \\
\hline $\begin{array}{c}\text { Number of children per } \\
\text { household }\end{array}$ & .0019479 & .0137703 & 0.14 & 0.888 \\
\hline $\begin{array}{l}\text { Indicators of the good } \\
\text { rainy season }\end{array}$ & .0155509 & .0207672 & 0.75 & 0.454 \\
\hline Good season indicators & -.254973 & .0468649 & -5.44 & 0.000 \\
\hline $\begin{array}{c}\text { Climate events of twenty } \\
\text { years ago }\end{array}$ & .0092141 & .0214436 & 0.43 & 0.667 \\
\hline Constance & 2.053437 & .2607194 & 7.88 & 0.000 \\
\hline \multicolumn{5}{|c|}{$\begin{array}{l}\text { Other statistics : Number of observations }=422 ; \text { Log likelihood } \\
\quad=-261.7681366 ; \text { AIC }(\text { Akaike's Information Criterion })= \\
1.306958 ; \quad \text { BIC }(\text { Schwarz'sBayesianCriterion })=-2380.929\end{array}$} \\
\hline
\end{tabular}

\subsection{Knowledge of vulnerability characteristics of food security}

For the estimation of the satisfaction of the food needs of agricultural households, the results shown in table-9 show that the majority of farmers $(86.01 \%)$ live in an economy of

Table 9: Knowledge of the current state of satisfaction of the primary needs of the peasant population of South-Kivu

\begin{tabular}{|c|c|c|c|}
\hline Variables & $\begin{array}{l}\text { Frequency: } \\
\mathrm{N}=422(\%)\end{array}$ & $\chi^{2}$ & $\begin{array}{c}\mathrm{P}- \\
\text { Value }\end{array}$ \\
\hline \multicolumn{4}{|c|}{ Coverage of needs by the income of your activity } \\
\hline Needs covered & $59(13.98)$ & 64.81 & $<0.001$ \\
\hline Needs not covered & $363(86.01)$ & 66.32 & $<0.001$ \\
\hline \multicolumn{4}{|c|}{ Consequences of non-coverage of needs } \\
\hline Difficulty in medical care & $45(10.66)$ & 10 & 0.040 \\
\hline Difficulty in education & $152(36.01)$ & 57.53 & $<0.001$ \\
\hline Rural exodus & $64(15.16)$ & 18.03 & 0.001 \\
\hline All the above & $88(20.85)$ & 2.11 & 0.715 \\
\hline $\begin{array}{l}\text { Difficulty in medical care } \\
\text { and education }\end{array}$ & $13(3.08)$ & 21.23 & $<0.001$ \\
\hline $\begin{array}{l}\text { Difficulty in medical care } \\
\text { and education }\end{array}$ & $53(12.55)$ & 65.20 & $<0.001$ \\
\hline $\begin{array}{l}\text { Difficulty in caring and } \\
\text { rural exodus }\end{array}$ & $7(1.65)$ & 19.42 & 0.001 \\
\hline \multicolumn{4}{|c|}{$\begin{array}{c}\text { Existence of other sources of income } \\
\end{array}$} \\
\hline Do exist & $205(48.57)$ & 8 & 0.092 \\
\hline Don't exist & $217(51.42)$ & 56.52 & $<0.001$ \\
\hline \multicolumn{4}{|c|}{ Other sources of income in rural areas } \\
\hline Trade & $145(34.36)$ & 9.44 & 0.051 \\
\hline Diaspora & $13(3.08)$ & 35.07 & $<0.001$ \\
\hline None & $264(62.55)$ & 87.96 & $<0.001$ \\
\hline
\end{tabular}

\subsection{Multiple regressions between food security and} climate variability

According to analyzes by the model of multiple regressions in relation to the evolution of elements of food security (general state of food security, food security according to the environment, global malnutrition, severe and moderate) and the variability of climatic factors (Annual and maximum annual temperatures and annual rainfall) over the years in South-Kivu, Table-10 shows that there is a negative relationship between the general state of food security and the year $(T=6.06, P<0.001)$ and the minimum temperature $(T=-2.03, P=0.004)$ and a positive relation to the maximum temperature $(T=4.96, \quad P<0.001)$ which means that the general state of food security is influenced by Variation in climatic factors. As the years pass in SouthKivu, food security deteriorates, especially in periods of

\section{Volume 6 Issue 12, December 2017}




\section{International Journal of Science and Research (IJSR) \\ ISSN (Online): 2319-7064}

Index Copernicus Value (2016): 79.57 | Impact Factor (2015): 6.391

minimum temperature, where it is very much deteriorated. These minimum temperatures that characterize periods of heavy rains favor the development of plant pests and diseases and damage crops until production falls. A slight improvement is observed as a function of the maximum annual temperatures. For the relationship between urban and rural food security and climate factors in South-Kivu, Table11 indicates that there is a negative relationship between food security in urban and rural areas with year $(T=6.38, P<$ $0.001)$ and the minimum temperature $(T=-3.01, P=0.003)$ and a positive relationship with the maximum temperature $(T$ $=5.08, P<0.001$ ).

This result indicates that the evolution of urban and rural food security in South-Kivu depends on the year and the minimum temperature which significantly deteriorates it, but the maximum temperature increases very significantly the number of malnutrition in urban areas and rural areas. As for the model of multiple regressions related to severe malnutrition, there is a very significant positive relationship between the year $(T=7.92, P<0.001)$. This result indicates that the evolution of severe malnutrition is a function of the year and is not related to temperature and rainfall in the region

All the prediction can be explained at $65.51 \%$ by combining the effects of climate change (Table-12) and in relation to the relationship between moderate malnutrition and climatic factors in South-Kivu, Table-13 shows that $(T=-6.32, P<$ $0.001)$, the minimum temperature $(T=-5.01, P<0.001)$, and the total annual rainfall $(T=-3.13, P=0.002)$, and a negative relationship between moderate malnutrition and the year. A result that means that moderate malnutrition is a function of temperature, rainfall in the region and year to the point that the prediction from this combination of the effects of climate change to moderate malnutrition can be explained at $68.43 \%$. Finally, according to the model of multiple regressions (Table-14) in relation to the relationship between global malnutrition and climatic factors in South-Kivu, there is a negative relationship between moderate malnutrition, minimum temperature $(T=-4.71, P<0.001)$ and rain $(\mathrm{T}=-$ 4.54, $P<0.001)$. This result indicates that overall malnutrition is a function of the minimum temperature and rain that degrade food security in the region by negatively impacting activities within agroecosystems.

Table 10: Analysis of the general evolution of the state of food security of the population according to the years, temperatures and rains of 2002-2015

\begin{tabular}{|c|c|c|c|c|c|}
\hline Term & Coef & SE Coef & T-Value & P-Value & VIF \\
\hline Constant & 6125 & 1010 & 6.06 & 0.000 & \\
\hline Year & -3.106 & 0.513 & -6.06 & $\mathbf{0 . 0 0 0}$ & 3.46 \\
\hline $\begin{array}{c}\text { Maximum } \\
\text { Temperature } \\
\text { (annualmean) }\end{array}$ & 9.51 & 1.92 & 4.96 & $\mathbf{0 . 0 0 0}$ & 7.50 \\
\hline $\begin{array}{c}\text { Minimum } \\
\text { Temperature } \\
\text { (annual mean) }\end{array}$ & -7.05 & 2.41 & -2.93 & $\mathbf{0 . 0 0 4}$ & 3.91 \\
\hline $\begin{array}{c}\text { Rainfall (annual } \\
\text { total) }\end{array}$ & -0.00126 & 0.00986 & 0.13 & -0.899 & 1.22 \\
\hline \multicolumn{7}{|c|}{ R-sq $=\mathbf{2 6 . 6 2 \%}$} & $\mathbf{S}=11.7666$ & \\
\hline
\end{tabular}

Table 11: Analysis of changes in the state of food security of the population in rural and urban areas according to the years, temperatures and rains of 2002-2015

\begin{tabular}{|c|c|c|c|c|c|}
\hline Term & Coef & SE Coef & $\begin{array}{c}T- \\
\text { Value }\end{array}$ & $\begin{array}{c}P- \\
\text { Value }\end{array}$ & VIF \\
\hline Constant & 2010 & 315 & 6.38 & 0.000 & \\
\hline Year & -1.019 & 0.160 & -6.38 & 0.000 & 3.46 \\
\hline $\begin{array}{c}\text { Maximum } \\
\text { Temperature } \\
\text { (annualmean) }\end{array}$ & 3.035 & 0.597 & 5.08 & 0.000 & 7.50 \\
\hline $\begin{array}{c}\text { Minimum Temperature } \\
\text { (annual mean) }\end{array}$ & -2.253 & 0.750 & -3.01 & 0.003 & 3.91 \\
\hline Rainfall (annual total) & 0.00056 & 0.00307 & 0.18 & 0.856 & 1.22 \\
\hline
\end{tabular}

Table 12: Analysis of the evolution of severe malnutrition according to the years, temperatures and rains of 2002-2015

\begin{tabular}{|c|c|c|c|c|c|}
\hline Term & Coef & SE Coef & $\begin{array}{c}T- \\
\text { Value }\end{array}$ & $\begin{array}{c}P- \\
\text { Value }\end{array}$ & $V I F$ \\
\hline Constant & -1254 & 156 & -8.06 & 0.000 & \\
\hline Year & 0.6256 & 0.0790 & 7.92 & 0.000 & 3.46 \\
\hline $\begin{array}{c}\text { Maximum } \\
\text { Temperature } \\
\text { (annualmean) }\end{array}$ & -0.083 & 0.295 & -0.28 & 0.780 & 7.50 \\
\hline $\begin{array}{l}\text { Minimum Temperature } \\
\text { (annual mean) }\end{array}$ & 0.189 & 0.370 & 0.51 & 0.610 & 3.91 \\
\hline Rainfall (annual total) & 0.00176 & 0.00152 & 1.16 & 0.249 & 1.22 \\
\hline \multicolumn{6}{|c|}{$\mathrm{R}-\mathrm{sq}=\mathbf{6 5 . 5 1} \%$} \\
\hline
\end{tabular}

Table 13: Analysis of trends in moderate malnutrition by years, temperatures and rains, 2002-2015

\begin{tabular}{|c|c|c|c|c|c|}
\hline Term & Coef & SE Coef & $\begin{array}{c}T- \\
\text { Value } \\
\end{array}$ & $\begin{array}{c}P- \\
\text { Value } \\
\end{array}$ & $V I F$ \\
\hline Constant & 546.0 & 81.8 & 6.67 & 0.000 & \\
\hline Year & -0.2624 & 0.0415 & -6.32 & 0.000 & 3.46 \\
\hline $\begin{array}{c}\text { Maximum } \\
\text { Temperature } \\
\text { (annualmean) }\end{array}$ & 0.169 & 0.155 & 1.09 & 0.280 & 7.50 \\
\hline $\begin{array}{c}\text { Minimum Temperature } \\
\text { (annual mean) }\end{array}$ & -0.977 & 0.195 & -5.01 & 0.000 & 3.91 \\
\hline Rainfall (annual total) & -0.0025 & 0.000799 & -3.13 & 0.002 & 1.22 \\
\hline
\end{tabular}

Table 14: Analysis of trends in overall malnutrition by years, temperatures and rains, 2002-2015

\begin{tabular}{|c|c|c|c|c|c|}
\hline Term & Coef & SE Coef & T-Value & P-Value & VIF \\
\hline Constant & 177 & 207 & 0.86 & 0.394 & \\
\hline Year & -0.059 & 0.105 & -0.56 & 0.577 & 3.46 \\
\hline $\begin{array}{c}\text { Maximum } \\
\text { Temperature } \\
\text { (annualmean) }\end{array}$ & -0.031 & 0.392 & -0.08 & 0.938 & 7.50 \\
\hline $\begin{array}{c}\text { Minimum } \\
\text { Temperature } \\
\text { (annual mean) }\end{array}$ & -2.321 & 0.492 & -4.71 & 0.000 & 3.91 \\
\hline $\begin{array}{c}\text { Rainfall (annual } \\
\text { total) }\end{array}$ & -0.009 & 0.00202 & -4.54 & 0.000 & 1.22 \\
\hline \multicolumn{7}{|c|}{$\mathrm{S}-\mathrm{sq}=45.20 \%$} & $\mathrm{~S}=2.40929$ & \\
\hline
\end{tabular}

\section{Discussion}

In this study, vulnerability refers to the characteristics of agroecosystems and food security that determine their ability to anticipate, cope, resist and recover from the impacts of climate hazards (temperature and rainfall), the variation of which would be natural or anthropogenic. 


\section{International Journal of Science and Research (IJSR) \\ ISSN (Online): 2319-7064}

Index Copernicus Value (2016): 79.57 | Impact Factor (2015): 6.391

The results obtained during the investigations show that the agro-ecosystems of South-Kivu are characterized by several conflicts that aggravate the activities in the agroecosystems, namely the conflicts on the land that oppose the farmers and the breeders. This reality is not peculiar to the territories of South-Kivu, it concerns all the eastern part of the DR Congo [15]. The agricultural environment in South-Kivu is subject to the pressure of disturbances of climatic factors, temperatures and rains, of which the farmers who are suffering the negative effects are currently dreading. Farmers are experiencing the effects of climate change as they do throughout the world [16]. This study confirms that there is a scarcity and small size of arable land that diminishes from father to son; Leading to excessive exploitation of lowlands and marginal soils, and no fallow within agroecosystems as reported [5]. The most extensive form of land acquisition is inheritance, in addition to the purchase, leasing and donation. The population is very poor with very little social infrastructure in good condition and profound social, cultural and environmental changes are observed. This state of affairs demonstrates the high vulnerability of the food production system to climate change.

Agricultural mechanization is still in its infancy and the workforce consists mainly of children who are members of rural families. The agricultural calendar is severely disrupted and crops are heavily attacked by pests and diseases (pests and diseases), but farmers do not have an effective means of dealing with them. This result meets what [17] points out for the city of Kinshasa. It had projected the effects of climate by 2050 and had shown that among the consequences of climate change on agriculture there would be disruption of the agricultural calendar and the attack of plants by diseases and pests which will find favorable conditions for development. The price of crop products is not regulated and therefore discourages farmers. Contrary to what is recommended by Sultan and hiscollaborators [18], there is no assurance of agricultural activities against climatic risks or warning systems in the region, which means that the food production system is very vulnerable to the adverse effects of climate and no accompanying measure to enhance their resilience. Farmers in the territories surveyed have now lost the benchmarks of good seasons because the indicators used in the past are no longer valid and have not been substituted by others. This broad knowledge of the characteristics of agro-ecosystems in South-Kivu is subject to a wide range of positive and negative influences within the population which reflects a perfect connection between the variability of climatic factors and the current state of conditions in agroecosystems of South-Kivu, which has a low adaptive capacity.

All major crops in the South-Kivu region are affected by the current fluctuations in climatic factors, which is what FAO 2011 describes as showing that world agricultural and livestock production systems are influenced by climate change and variability. Families are plethoric with an average of 8 people, above the average of 2014 which was 7,[9]. The demand for food increases as production decreases among peasants. Young people out of school are less interested in agriculture and prefer the rural exodus without suspecting the consequences. The peasant farmers of South-Kivu show that their environment offers no other possibilities other than the small trade to which a small part of the peasant population in search of measures to adapt to climate change resorts. However, petty trading is also a victim of non-regulation of prices and the climate of incompetent business. It is important to secure the food production sector to ensure good living conditions for poor people in the peasant communities of South-Kivu already under pressure from the cumulative effects of climate change and environmental degradation.

Whether it is the general state of food security, severe, moderate and global malnutrition, analyzes of multiple regressions have established that there are significant relationships and connections with climate factors over the years in the region. As the years pass, temperatures and rains are disrupted and food security deteriorates considerably in South-Kivu.

All of these above-mentioned characteristics reflect a high vulnerability of agroecosystems and food security to climate change. It is therefore necessary to develop adaptation strategies to strengthen the capacity of agro-ecosystems to provide services to populations in constraining situations. This result shows many types of vulnerabilities that better describe the realities of South-Kivu, to which we can add some avenues of alternative solutions (Table-15)

Table 15: Types of vulnerabilities of agroecosystems and food security to climate change in South Kivu and some alternatives.

\begin{tabular}{|c|c|c|}
\hline $\begin{array}{c}\text { Types of } \\
\text { vulnerability }\end{array}$ & \begin{tabular}{|l|}
$\begin{array}{l}\text { Indicators and } \\
\text { characteristics }\end{array}$ \\
\end{tabular} & $\begin{array}{c}\begin{array}{c}\text { Alternatives for local } \\
\text { capacity building }\end{array} \\
\end{array}$ \\
\hline Physical & $\begin{array}{c}\text { No agricultural service } \\
\text { roads, scarcity and } \\
\text { crampedness of soil, } \\
\text { soil reclamation by } \\
\text { rains }\end{array}$ & $\begin{array}{l}\text { Development of agricultural } \\
\text { service roads, Improving of } \\
\text { soil quality by conservatory } \\
\text { agriculture and agroforestry }\end{array}$ \\
\hline Social & $\begin{array}{c}\text { FamiliesLand disputes } \\
\text { between farmers and } \\
\text { herders, } \\
\text { No access to all } \\
\text { necessary food }\end{array}$ & $\begin{array}{c}\text { Awareness raising for } \\
\text { rational procreation, Making } \\
\text { a land mediation between the } \\
\text { parties, Establish an } \\
\text { adequate food policy, } \\
\text { Develop other sources of } \\
\text { income }\end{array}$ \\
\hline Ecological & $\begin{array}{c}\text { Soils are degraded and } \\
\text { excessive exploitation } \\
\text { of bottoms and } \\
\text { marginal lands, } \\
\text { Agricultural calendar } \\
\text { very disturbed, Loss of } \\
\text { landmarks or indicators } \\
\text { of good seasons, } \\
\text { Rugged topography at } \\
\text { many places. } \\
\end{array}$ & $\begin{array}{c}\text { Ecological restoration of } \\
\text { degraded and marginal soils, } \\
\text { soil conservation. Practicing } \\
\text { conservation agriculture, } \\
\text { Use anti-erosion hedges, } \\
\text { Adjust agricultural calendar } \\
\text { by crop and cropping season }\end{array}$ \\
\hline Economic & \begin{tabular}{|} 
Price less interesting \\
and discouraging; Poor \\
households with very \\
low income, No \\
involvement of the \\
government in the \\
regulation of prices of \\
agricultural products.
\end{tabular} & $\begin{array}{l}\text { Involvement of stakeholders } \\
\text { and decision-makers in the } \\
\text { regulation of prices, costs } \\
\text { and benefits in agricultural } \\
\text { activities }\end{array}$ \\
\hline Policy & $\begin{array}{c}\text { Impairment of political } \\
\text { services in the } \\
\text { regulation of business; } \\
\text { No zoning regulations }\end{array}$ & $\begin{array}{l}\text { Ensure a sound policy to } \\
\text { improve the business } \\
\text { climate; Development of } \\
\text { social security networks }\end{array}$ \\
\hline
\end{tabular}




\section{International Journal of Science and Research (IJSR) \\ ISSN (Online): 2319-7064}

Index Copernicus Value (2016): 79.57 | Impact Factor (2015): 6.391

\begin{tabular}{|c|c|c|}
\hline Technique & $\begin{array}{l}\text { Poor farming practices, } \\
\text { No farmer supervision, } \\
\text { No agricultural } \\
\text { mechanization, No } \\
\text { fallow, Labor mainly } \\
\text { composed of children, } \\
\text { Low adoption of } \\
\text { techniques of soil } \\
\text { regeneration. }\end{array}$ & $\begin{array}{l}\text { To supervise and group } \\
\text { farmers for common } \\
\text { purposes, To supplement the } \\
\text { labor force by promoting } \\
\text { agricultural mechanization; } \\
\text { Extend the techniques of soil } \\
\text { regeneration (techniques of } \\
\text { conservation agriculture and } \\
\text { agroecology) }\end{array}$ \\
\hline Institutional & $\begin{array}{l}\text { No insurance of } \\
\text { agricultural activities } \\
\text { against climatic risks, } \\
\text { No institution of } \\
\text { management of the } \\
\text { risks and disasters in } \\
\text { the peasant circles. }\end{array}$ & $\begin{array}{c}\text { Establish a good policy } \\
\text { against the risks of climatic } \\
\text { hazards, Promoting alert } \\
\text { systems. }\end{array}$ \\
\hline
\end{tabular}

\section{Conclusion}

It is in the context of adaptation to climate change and sustainable management of natural resources for the promotion of food security that this study on the vulnerability of agroecosystems and food security to climate change was conducted in South-Kivu, through surveys and a survey questionnaire designed and administered to 422 household heads in five territories (Kabare, Kalehe, Idjwi, Walungu and Uvira) for two consecutive years (2015 and 2016).

Several difficulties are encountered by farmers in carrying out their work, including lack of financial means for field work, disturbances and uncertainties of climatic factors, many land conflicts, plants attacked by pests, low yields crop and crop prices, lack of agricultural service roads, inadequate agricultural land, lack and scarcity of arable land, noninvolvement of the State in the regulation of agricultural activities, degraded soil quality and labor mainly consisting of children belonging to households, poor adoption of sustainable agriculture techniques and practices, etc., this would indicate a weak capacity to react and adapt.

Given the full range of agroecosystems characteristics and food security, which clearly reflect the vulnerability of these sectors to current climate change, the practice of conservation agriculture and a study of endogenous adaptation strategies of agroecosystems and food security to climate change are of great importance in the context of sustainable natural resource management in order to strengthen the local capacity for adaptation and resilience of these systems in South-Kivu.

\section{References}

[1] Tirado M.C., Crahay P., Hunnes D., Cohen M., Denton F., Lartey A, "Climate Change and Nutrition in Africa, Focus on Sub-Saharan Africa" 5: 3-29, 2012. (Translation)

[2] Hamani D.O., "Adapting agriculture to climate change: the case ofDepartment of Tera in Niger. Alexandria" (Egypt): Master thesis in Development and Environment, unpublished, 2007.(Translation)

[3] IPCC, "Climate Change 2007.The Physical Science Basis. Contribution of Working Group I to the
Fourth Assessment" Report of the Intergovernmental Panel on Climate Change, 2007.

[4] OCDE, "Climate Change and Agriculture: Impacts, Adaptation, Mitigation and Options,"2009.

[5] Byenda M.B., "Degradation of family farming agroecosystems: threat and Challenge of generations in South-Kivu.'International Journal of Innovation and Applied Studies, 17: 43-56, 2016. (Translation)

[6] Boureima M., Abasse AT, Sotelo MC., Weber JC., Katkore B., Mounkoro B., Dakouo JM., Samake O., Sigue H., Bationo BA., Diallo BO., "Analyse participative de la vulnérabilité et de l'adaptation aux changements climatiques: un guide méthodologique". OccasionalPaper 19. Nairobi: World Agroforestry Centre., 2012.

[7] Kanyenga L.A., "Adaptation of varietal accessionsof common bean (Phaseolus Vulgaris L.) Fortified bio."Influence of pedoclimatic conditions and technicalroutes on the performance and stability of yield andmicronutrients in the different agroecological zones ofthe DRC" $\mathrm{PhD}$ thesis, UNILU, Unpublished,2012.(Translation)

[8] CPI, "Report of the 10th cycle of analysis of the Integrated Framework of Food Security (IPC)", 2014. (Translation)

[9] WFP (World Food Program), "Global analysis of food security and Vulnerability (cfsva)"2014. 125 pages

[10] CFS, "Coming to terms with terminology: Food security, Nutrition security, Food Security and nutrition, Food and nutrition security, Committee on World Food Security (CFS)",2012.

[11] Roberto C, Hamid EB, Philipp D, Gianluigi C, Noureddin D., "Food System Sustainability and Food Security: Connecting the Dots," Journal of FoodSecurity, 2( 1): 13-22, 2014.

[12] Tubiana L., Gemenne F., Magnan A, "Anticipating for adaptation: the new challenge of Climate change," Pearson France, Paris, 2010.(Translation)

[13] Ahmadou L., "The impact of climate change on food security in Senegal," (Provisional version), 2014.(Translation)

[14] IPCC,"Climate change 2001: Impacts, Adaptation \& Vulnerability. Contribution of Working Group 2 to the Third Assessment Report” 2001.

[15] ONU-Habitat (Programme des Nations Unies pour les établissements humains),"Guide de Médiation Foncière: Basée sur l'Expérience de l'Est de la République Démocratique du Congo. ”2013.

[16] Gutu T, Bezabih E, Mengistu K., "A timeseries analysis of climate variability and its impacts onfood Production in north shewa zone in Ethiopia,"In African Crop Science Journal, 20 : 261 - 274, 2012.

[17] Bangabutu X., "Impact of climate change andclimate variability on the Rainfall regime of the city of Kinshasa, University of Kinshasa”, 2007.(Translation)

[18] Sultan B., Alhassane A., Barbier B., Baron C., Tsogo MBM., Berg A., Dingkuhn M., Fortilus J., Kouressy M., Leblois A., Marteau R., Muller B., Oettli P., Quirion P., Roudier P., Traoré SB. et Vaksmann M., "La question de la vulnérabilité et de l'adaptation de l'agriculture sahélienne au climat au sein du 
programme AMMA," in La Météorologie - Spécial AMMA : $64-72,2012$.

\section{Author Profile}

Byenda Mutuga Bienfait received the Licence degree (BAC-5) in Biologyfrom TTC Bukavu and his Master in Sciences degree from Peace Africa University. Specialist in Biodiversity and Ecosystems.He is now Teacher and Searcher in Climate change, Agroecology and Natural ressources management domain.Institute: ISEAV Mushweshwe. Laboratory: Unit of teaching and researching in environment and agrosciences (UREA, of Bukavu Center University: UBC).DRCongo, SouthKivu

Volume 6 Issue 12, December 2017

www.ijsr.net 